Jurnal Abdimas Berdaya : Jurnal Pembelajaran, Pemberdayaan dan Pengabdian Masyarakat

Volume 4 Nomor 02 Tahun 2021

P-ISSN: $2685-1563$

e-ISSN: 2720 - 9768

\title{
Pelatihan Pembuatan Sarapan Sehat
}

\section{Training For Making Healthy Breakfast}

\author{
Diena M Lemy ${ }^{1)}$, Amelda Pramezwary ${ }^{2)}$, Valencia $^{3)}$, Christine Junus ${ }^{4)}$ \\ 1,2,3,4 Universitas Pelita Harapan, Indonesia \\ e-mail: 1diena.lemy@uph.edu, ${ }^{2}$ amelda.pramezwary@uph.edu, \\ ${ }^{3}$ valencia_yang@yahoo.com, ${ }^{4}$ Christine_junus@yahoo.com
}

\begin{abstract}
Abstrak: Situasi pandemi COVID-19 yang semakin memburuk menjadikan para lanjut usia (lansia) menjadi sangat rentan dan beresiko terhadap ancaman penyebaran virus COVID-19 karena virus ini dapat dengan cepat menyerang sistem pertahanan tubuh. Makanan sehat bergizi, ketersediaan kebutuhan dasar, obat-obatan serta perawatan sosial menjadi prioritas penting yang harus diperhatikan oleh anggota keluarga lainnya untuk menjaga keberlangsungan hidup lansia. Lansia di Panti Wreda \& Panti Asuhan Kemah Beth Shalom berkeinginan untuk hidup lebih sehat dan mengonsumsi makanan yang baik bagi kesehatan tubuh, serta menambah pengetahuan mengenai beragam jenis makanan. Oleh karena itu, tim mahasiswi Fakultas Pariwisata Program Studi Pengelolaan Perhotelan Universitas Pelita Harapan akan mengadakan pelatihan pembuatan sarapan sehat kepada para lansia di Lansia di Panti Wreda \& Panti Asuhan Kemah Beth Shalom Tangerang Selatan.Tim Pengabdian kepada Masyarakat (PkM) akan melakukan pelatihan sederhana bagaimana cara membuat sarapan sehat kepada para lansia yang berada di Panti Kemah Beth Shalom dengan bahan dasar yang bernutrisi, mudah didapatkan, dan diolah menjadi makanan enak nan sehat. Kegiatan ini dilaksanakan dan dihadiri sekitar 5 (lima) orang lansia, pengurus panti, dan ketua tim dengan menggunakan peralatan dan bahan yang mudah didapatkan. Tim PkM akan melaksanakan kegiatan ini dengan cara tatap muka secara langsung di lokasi dan secara daring melalui ruang rapat aplikasi ZOOM. Pelatihan ini diharapkan dapat memotivasi para pengurus dan lansia untuk hidup lebih sehat dengan mengonsumsi makanan sehat serta menambah keterampilan dalam membuat makanan sarapan sehat bernutrisi.
\end{abstract}

Kata Kunci: Lansia, Sarapan Sehat, Pengabdian kepada Masyarakat

Abstract: The worsening situation of the COVID-19 pandemic has made the elderlies very vulnerable and at risk of the threat of spreading the COVID-19 virus since this virus can quickly attack the body's defense system. Healthy nutritious food, availability of basic needs, medicines and social care are top priorities that must be considered greatly by other family members to maintain the survival of the elderlies. The elderlies at Panti Wreda \& Panti Asuhan Kemah Beth Shalom desire to live a healthier life and consume healthy food as well as increase their knowledge about various types of food. Therefore, the student team of the Faculty of Tourism of the Hospitality Management Study Program, Universitas Pelita Harapan will conduct a training on making healthy breakfast for the elderlies at Panti Kemah Beth Shalom, South Tangerang with ingredients that are nutritious, easy to get, and processed into delicious and healthy food. This activity was carried out and attended by about 5 (five) elderly people, orphanage administrators, and team leaders using easily available equipment and materials. The PkM team will carry out this activity face-to-face directly on site and online through the ZOOM application meeting room. This training is expected to motivate the administrators and the elderly to live a healthier life by consuming healthy food and increase their skills in making nutritious healthy breakfast foods.

Keywords: Elderlies, Healthy Breakfast, Community Service

JURNAL ABDIMAS BERDAYA: Volume 4 Nomor 02 Tahun 2021 


\section{A. Pendahuluan}

Kondisi pandemi covid-19 yang melanda seluruh dunia, memberi dampak negatif juga bagi kondisi perekonomian. Indonesia juga tidak terlepas dari masalah tersebut. Sebagian masyarakat harus berhenti dari pekerjaan atau bekerja paruh waktu, karena permintaan pasar berkurang. (Hubner et al., 2021). Menurut Sitorus et al. (2021) usaha Food and Beverage sangat sesuai untuk diperkenalkan pada masa pandemic Covid-19 dan bagaimana cara untuk bangkit kembali. Konsumsi makanan merupakan bagian yang tidak terpisahkan dari kehidupan sehari-hari yang memberikan rezeki untuk menunjang tubuh tetapi juga memenuhi banyak kebutuhan manusia lainnya, termasuk kesenangan dan hubungan sosial (Bublitz et al., 2019; Bublitz et al., 2013) Masyarakat saat ini ditantang oleh meningkatnya prevalensi masalah kesehatan, dengan banyak berhubungan dengan konsumsi makanan. Secara tradisional, kesehatan telah dikonseptualisasikan sebagai melibatkan dalam dan di luar faktor individu (Bronfenbrenner, 2005). Ketika berhadapan dengan makanan, individu dipandang berinteraksi dengan lingkungan makanan di sekitarnya secara timbal balik (Roberto et al., 2015). Studi menurut Bogomolova et al. (2020) dalam meningkatkan pengetahuan konsumen mengenai pilihan makanan yang lebih sehat dengan menerapkan 15 strategi baru yang dikembangkan oleh konsumen untuk mendukung kesehatan dan kesejahteraan. Panti Wreda \& Panti Asuhan Kemah Beth Shalom merupakan panti mandiri, berada di kawasan Bumi Serpong Damai (BSD), Tangerang Selatan. Tujuan berdirinya panti wreda ialah untuk membantu, merawat, dan memberikan kehidupan yang layak kepada para lansia. Panti Wreda \& Panti Asuhan Kemah Beth Shalom berlokasi Gang Mushola Nurul Amal Jl. Ciater Rw. Mekar Jaya No.14, RT.002/RW.001, Rawa Mekar Jaya, Serpong, Kota Tangerang Selatan, Banten 15310. Panti Kemah Beth Shalom diresmikan di bulan Mei tahun 2013. Awal berdirinya Panti Kemah Beth Shalom dibangun karena kerinduan bapak gembala Gereja Bethel Indonesia (GBI) Intermark, yaitu bapak Stephen E. Purwanto, beliau melihat banyak lansia yang hidup terlantar, tidak terurus dengan baik oleh anak-anaknya maupun anggota keluarga lainnya, sehingga ada seorang pekerja gereja yang tergerak hatinya untuk memberikan sebagian dari lahan kosong miliknya untuk membangun panti tersebut. Karena Panti Kemah Beth Shalom adalah panti tak berbayar (sosial), maka sisa lahan lainnya digunakan untuk menanam sayur organik, ternak ikan, dan ayam kampung untuk menunjang biaya operasional panti.

Panti Kemah Beth Shalom memiliki lahan pemberdayaan yang cukup luas untuk bercocok tanam yang dapat menunjang berbagai kegiatan, seperti kegiatan kelas memasak yang sebagian bahan-bahannya dapat dipetik langsung dari hasil perkebunan di halaman panti. Kegiatan ini ditujukan bagi lansia perempuan maupun laki- laki, hal ini dapat menjadi salah satu aktivitas lansia dan tentunya dapat menambah pengetahuan serta keterampilan lansia dalam memasak. 


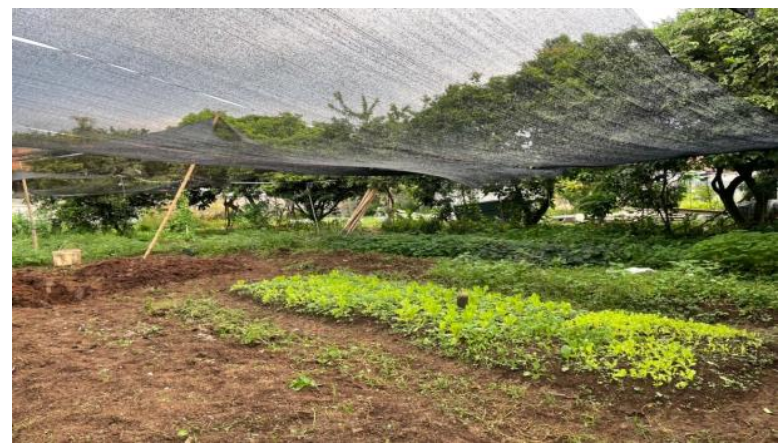

Gambar 1. Lahan untuk Bercocok Tanam di Panti Kemah Beth Shalom Sumber : Pantai Kemah Beth Shalom (2021)

Tim PkM telah melakukan observasi ke lokasi mitra sasaran dan ditemukan bahwa Panti Kemah Beth Shalom hanya memiliki tiga orang pengurus di bagian dapur yang menjalankan kegiatan seluruh masak-memasak. Pengurus dapur tidak hanya memasak untuk lansia, tetapi juga bagi anak-anak asuh yang tinggal di panti tersebut, karena Panti Kemah Beth Shalom merupakan panti wreda sekaligus panti asuhan. Maka dapat disimpulkan bahwa kekurangan sumber daya manusia menjadi permasalahan yang dihadapi oleh mitra sasaran tim PkM.

Solusi yang ditawarkan terkait permasalahan yang muncul pada mitra sasaran, meliputi:

a. Penyuluhan

Penyuluhan mengenai cara memasak sarapan mudah, sehat, dan bergizi bagi para lansia agar lansia dapat membuat sarapan sendiri yang dapat meringankan pekerjaan pengurus maupun dapat menambah pengetahuan dan keterampilan memasak. Selain itu, kegiatan memasak dapat menjadi aktivitas fisik atau hobi baru bagi para lansia agar semakin aktif untuk mengisi hari- hari. Aktivitas fisik yang dilakukan secara terus-menerus dapat bermanfaat bagi kesehatan lansia, seperti mencegah depresi (Abdi et al., 2017)

b. Edukasi

Memberikan motivasi dan menambah pengetahuan bagi pengurus di mitra sasaran dengan melakukan penyuluhan memasak sarapan mudah, sehat, dan bergizi. Selain itu, penyuluhan ini dapat menjadi ide baru bagi pengurus untuk dapat mengatasi kebosanan terhadap menu makanan yang sama dengan memberikan berbagai macam menu sarapan baru yang enak dan sehat dengan bahan-bahan dasar yang mudah didapatkan, metode pembuatan yang mudah, dan tentunya tidak akan memberatkan para pengurus maupun lansia.

\section{B. Metode}

Dalam upaya meminimalisir permasalahan yang terjadi pada Panti Kemah Beth Shalom, Tim PkM akan melakukan penyuluhan mengenai cara memasak sarapan dengan cara mudah dan dengan bahan-bahan yang mudah didapatkan. Pelaksana PkM menyampaikan materi secara singkat mengenai resep masakan yang akan dibuat. Para lansia dan pengurus juga berperan aktif dalam mempersiapkan bahan-bahan kemudian 
ikut memasak dengan mengikuti arahan dari tim PkM. Pandemi COVID-19 tentu menjadi tantangan baru yang dihadapi oleh para lanjut usia (lansia) karena virus ini menyerang sistem pertahanan tubuh secara cepat yang menjadikan lansia menjadi salah satu kategori usia yang sangat rentan dan beresiko terhadap dampak penyebaran virus berbahaya ini (Abidin \& Julianto, 2020) sangat penting buat masyarakat untuk menjaga pola makan yang sehat, bergizi, dan gizi seimbang untuk membantu meningkatkan proses kekebalan tubuh (Akbar \& Aidha, 2020) Dengan kuatnya sistem kekebalan tubuh dapat melawan bakteri, virus, dan organisme penyebab penyakit yang bisa disebabkan oleh bersentuhan dengan orang atau barang, makanan yang dikonsumsi, dan udara yang dihirup (Kementerian Kesehatan RI, 2020).

Memasuki usia lanjut merupakan hal yang biologis dan tidak dapat terelakkan setiap manusia. Para lansia yang mencapai pada tahap ini tentu berharap dapat hidup sejahtera dan menikmati masa tuanya. Namun bertambahnya usia, kondisi kesehatan lansia tentu tidak optimal lagi. Lansia juga memiliki masalah gizi yang berkaitan dengan menurunnya aktivitas biologis tubuhnya. Konsumsi pangan yang kurang seimbang akan memperburuk keadaan dari lansia tersebut (Senjaya, 2015). Kebutuhan gizi lansia yang tercukupi dapat membantu dalam proses beradaptasi atau menyesuaikan diri dengan perubahan- perubahan yang dialaminya, selain itu dapat menjaga kelangsungan pergantian sel-sel tubuh sehingga dapat memperpanjang usia. Selain itu, lansia juga perlu menjaga kondisi keberfungsian fisik dan kognitif dengan cara melakukan aktivitas fisik, karena dengan melakukan aktivitas fisik secara teratur dapat mendukung kesehatan, menambah pengetahuan dan keterampilan, serta menjaga daya ingat lansia (Nuriana et al., 2019). Oleh karena itu, tim PkM akan melakukan pelatihan membuat sarapan sehat agar membawa sejumlah manfaat terhadap aspek kehidupan lansia seperti: Memotivasi para lansia di Panti Kemah Beth Shalom untuk memulai hidup sehat. Memotivasi lansia untuk beraktivitas dengan kegiatan memasak sehingga seluruh aspek kesehatan lansia dapat terjaga dengan baik. Di sisi lain, para pengurus panti juga mendapatkan ide baru memasak sarapan sehat dan beban pekerjaan pengurus dapat berkurang dengan adanya bantuan memasak dari para lansia.

Khalayak sasaran kegiatan PkM ini ditujukan untuk para lansia dan pengurus Panti Kemah Beth Shalom sebanyak 5-10 orang. Kegiatan PkM melalui tiga proses tahapan dimulai dari tahap persiapan, pelaksanaan, dan evaluasi serta tindakan lanjutan. Berikut ketiga proses tahapan yang dijalankan oleh tim PkM: Pada tahap awal sebelum dilaksanakan kegiatan Pengabdian kepada Masyarakat, tim pelaksana terlebih dahulu melakukan survei secara lansung di Panti Wreda \& Panti Asuhan Kemah Beth Shalom agar mengetahui kondisi panti tersebut yang meliputi fasilitas sarana dan prasarana yang dapat menunjang kegiatan PkM. Kemudian menyiapkan proposal kegiatan, barang dan bahan apa saja yang diperlukan, serta materi yang akan dijelaskan kepada peserta lansia.

Kegiatan PkM ini dilaksanakan oleh tim mahasiswi dan dosen Universitas Pelita Harapan yang terdiri dari satu orang dosen dan dua orang mahasiswi. Kegiatan ini 131 
dihadiri peserta yang terdiri dari para lansia dan pengurus sebanyak 5-10 orang. Tim PkM akan menjelaskan secara singkat dan rinci mengenai pentingnya sarapan yang sehat, lalu akan melakukan penyuluhan mengenai cara memasak yang mudah dengan bahan-bahan yang mudah didapatkan. Menu masakan yang akan dipraktikkan oleh tim PkM terdiri dari dua menu, yaitu: Sup Tahu Tempe Telur Sayur dan Banana Pancake. Setelah tim PkM mempraktikkan kedua jenis masakan tersebut, para peserta dapat bertanya dan mencicipi langsung masakan yang telah dibuat.

Pelatihan ini diharapkan dapat memotivasi para lansia untuk memulai hidup sehat dengan cara mengonsumsi makanan sehat, menambah pengetahuan dan keterampilan memasak, mendorong para lansia agar aktif dalam kehidupan sehari-hari dengan memasak, serta memberi ide baru bagi para pengurus dalam membuat sarapan yang lezat dan bergizi. Kegiatan ini dilaksanakan secara langsung di Panti Kemah Beth Shalom dan secara daring melalui ruang rapat aplikasi ZOOM. Tahap evaluasi dan tindakan lanjutan ditujukan agar kegiatan $\mathrm{PkM}$ dapat berjalan dengan efektif dan membawa manfaat bagi peserta. Evaluasi dilakukan pada akhir tahap kegiatan yang memuat tingkat keberhasilan kegiatan tersebut dengan membagikan kuesioner kepada para peserta. Setelah menilai dari hasil analisis kuesioner, tim PkM akan menindaklanjuti dengan memberikan bimbingan agar pihak mitra sasaran terus melanjutkan kegiatan membuat sarapan sehat agar menciptakan pola hidup yang lebih baik dan meningkatkan kesejahteraan hidup para lansia.

Kegiatan Pkm lainnya yang dilakukan oleh (Juliana et al., 2020; Lemy et al., 2021) yang melakukan pelatihan membuat salad sayur hidroponik dan mengenai kreasi tteok yang memberikan manfaat bagi masyarakat untuk menekuni bisnis makanan sehat serta memasarkan produk menggunakan e-commerce. Studi dari Vanheuvelen \& Vanheuvelen (2017) mengkonfirmasi bahwa makan buah-buahan segar dan sayuran yang padat nutrisi sering dikaitkan dengan hasil kesehatan yang baik.

\section{Hasil dan Pembahasan}

Untuk mengukur keberhasilan dari kegiatan pelatihan yang tim penulis lakukan kepada peserta di Panti Kemah Beth Shalom, tim penulis memberikan pre-test dan posttest yang berisikan 6 pertanyaan mengenai materi pelatihan yang harus diisi oleh masing-masing peserta. Lalu tim penulis menilai jawaban dari pre-test dan post-test yang sudah diisi, dari jawaban tersebut tim penulis menggunakan program SPSS untuk menilai tingkat keberhasilan dari pelatihan tersebut.

Uji normalitas dilakukan untuk mengetahui apakah distribusi data mengikuti atau mendekati distribusi normal atau bebas (Sugiyono, 2011). Dalam laporan ini uji normalitas dilakukan setelah penilaian pre-test dan post-test dilakukan dan dihitung dengan menggunakan uji Shapiro-Wilk karena jumlah responden kurang dari 50.

Perumusan hipotesis:

$\mathrm{H}_{0}=$ Data pre-test dan post-test dari pelatihan PKM kepada peserta panti jompo kemah

Beth Shalom berdistribusi normal 
$\mathrm{H}_{1}=$ Data pre-test dan post-test dan pelatihan PKM kepada peserta panti jompo kemah Beth Shalom berdistribusi bebas

Dasar Pengambilan Keputusan:

Jika sig > 0,05 maka data berdistribusi normal atau $\mathrm{H}_{0}$ diterima Jika sig $<0,05$ maka data berdistribusi bebas atau $\mathrm{H}_{0}$ ditolak

Adapun hasil hitung dan uji normalitas pre-test dan post-test adalah sebagai berikut:

Tabel 1. Uji Normalitas

\begin{tabular}{|l|l|l|l|l|l|l|}
\hline \multicolumn{8}{|c|}{ Tests of Normality } \\
\hline & Kolmogorov-Smirnov & \multicolumn{3}{|c|}{ Shapiro-Wilk } \\
\cline { 2 - 7 } & Statistic & df & Sig. & Statistic & df & Sig. \\
\hline Pre-test &, 206 & 21 &, 000 &, 737 & 21 &, 000 \\
\hline Post-test &, 412 & 21 &, 000 &, 609 & 21 &, 000 \\
\hline \multicolumn{6}{|c|}{ a. Lilliefors Significance Correction } \\
\hline
\end{tabular}

Pada table hasil hitung uji normalitas Shapiro-Wilk dapat diketahui bahwa nilai Sig. pre-test 0.000 dan nilai Sig. post-test 0.000 . Hal ini menunjukan, nilai Sig. pretest $<0.05$ dan nilai Sig. post-test $<0.05$ sehinga dapat ditarik kesimpulan bahwa hasil uji normalits dari pre-test dan post-test berdistribusi bebas.

\section{Uji Wilcoxon}

Untuk mengetahui perbedaan pengisian pre-test dari pelatihan PKM maka digunakan teknis analisis uji Wilcoxon. Responden berjumlah 10 orang.

Perumusan hipotesis:

$\mathrm{HO}=$ Tidak terdapat perbedaan wawasan pada peserta panti jompo kemah Beth Shalom sebelum dan sesudah diberikan pelatihan PKM

H1 = Terdapat perbedaan wawasan pada peserta panti jompo kemah Beth Shalom sebelum dan sesudah diberikan sebelum dan sesudah diberikan pelatihan PKM.

Dasar pengambilan keputusan:

Jika Sig. (2-tailed) > 0.05 maka H0 diterima Jika Sig. (2-tailed) < 0.05 maka H0 ditolak Adapun hasil hitung dari uji Wilcoxon pre-test adalah sebagai berikut:

Tabel 2 Wilcoxon Test

Ranks

\begin{tabular}{|c|l|c|c|c|}
\hline \multicolumn{2}{|c|}{} & $\mathrm{N}$ & $\begin{array}{c}\text { Mean } \\
\text { Rank }\end{array}$ & $\begin{array}{c}\text { Sum of } \\
\text { Ranks }\end{array}$ \\
\hline \multirow{2}{*}{$\begin{array}{c}\text { Posttest }- \\
\text { Pretest }\end{array}$} & $\begin{array}{l}\text { Negative } \\
\text { Ranks }\end{array}$ & $0^{\mathrm{a}}$ &, 00 &, 00 \\
\cline { 2 - 5 } & $\begin{array}{l}\text { Positive } \\
\text { Ranks Ties } \\
\end{array}$ & $\begin{array}{c}20^{\mathrm{b}} \\
1^{\mathrm{c}}\end{array}$ & 10,00 & 200,00 \\
\cline { 3 - 5 } & Total & 21 & & \\
\hline
\end{tabular}



a. $\quad$ Posttest $<$ Pretest
b. Posttest $>$ Pretest
c. $\quad$ Posttest $=$ Pretest

Tabel 3.Uji Wilcoxon

Test Statistics ${ }^{a}$

\begin{tabular}{|c|c|}
\hline & $\begin{array}{l}\text { Posttest- } \\
\text { Pretest }\end{array}$ \\
\hline Z & $-4,028^{\mathrm{b}}$ \\
\hline $\begin{array}{lll}\begin{array}{l}\text { Asymp. } \\
\text { tailed) }\end{array} & \text { Sig. } & \text { (2- } \\
\end{array}$ & ,000 \\
\hline
\end{tabular}

a. Wilcoxon Signed Ranks Test

b. Based on negative ranks.

Dari tabel diatas dapat disimpulkan bahwa nilai Sig. sebesar 0.000 karena nilai Sig. <0.05 maka sesuai dengan dasar pengambilan keputusan dalam uji Wilcoxon dapat disimpulkan bahwa terdapat perbedaan wawasan pada peserta panti jompo kemah Beth Shalom sebelum dan sesudah pelatihan. Kegiatan PkM diharapkan dapat membawa dampak positif bagi para peserta. Para Lansia dapat termotivasi untuk beraktivitas secara aktif untuk mengisi hari-harinya mulai dengan memasak. Selain itu, memasak juga dapat menambah pengetahuan, melatih keterampilan motorik, menghambat kepikunan, dan menjaga kestabilan kesehatan mental (Utami et al., 2020; Utami \& Hariyanto, 2020). Di sisi lain, para pengurus panti dapat mengurangi beban pekerjaan dengan bantuan para lansia serta mendapat ide baru dalam mengolah makanan sehat.

\section{Simpulan}

Simpulan dari seluruh kegiatan ini adalah terdapat perbedaan wawasan pada peserta panti jompo kemah Beth Shalom sebelum dan sesudah pelatihan, pentingnya memberikan materi dan cara tentang pelatihan membuat sarapan sehat Kegiatan PkM diharapkan dapat membawa dampak positif bagi para peserta. Para Lansia dapat termotivasi untuk beraktivitas secara aktif untuk mengisi hari-harinya mulai dengan memasak. Kegiatan ini sangat berguna untuk Universitas Pelita Harapan untuk menjalin kerjasama dengan panti jompo dalam membuat sebuah kegiatan pengabdian kepada masyarakat. Rekomendasi untuk kegiatan ini dapat terus berkelanjutan melaksanakan kegiatan ini secara offline maupun hybrid di lain kesempatan serta melakukan kegiatan yang sama kepada panti jompo lainnya. 
Berikut dilampirkan foto dokumentasi kegiatan pengabdian kepada masyarakat

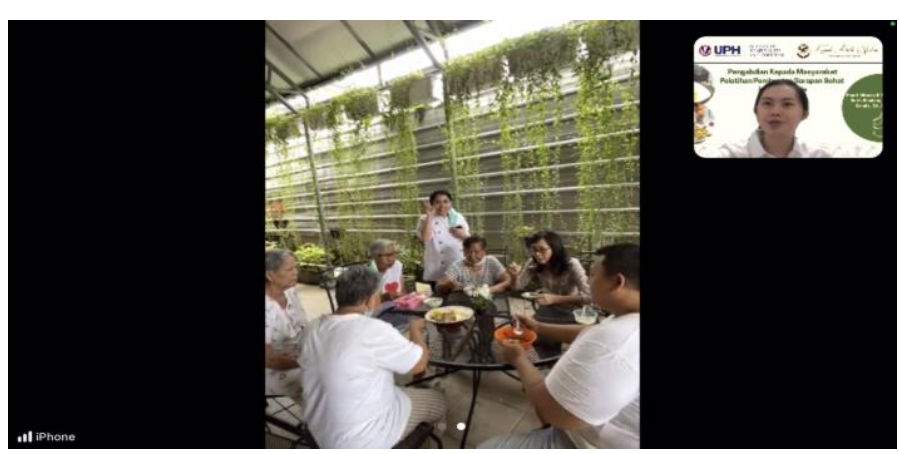

Gambar 2. Kegiatan Sosialisasi

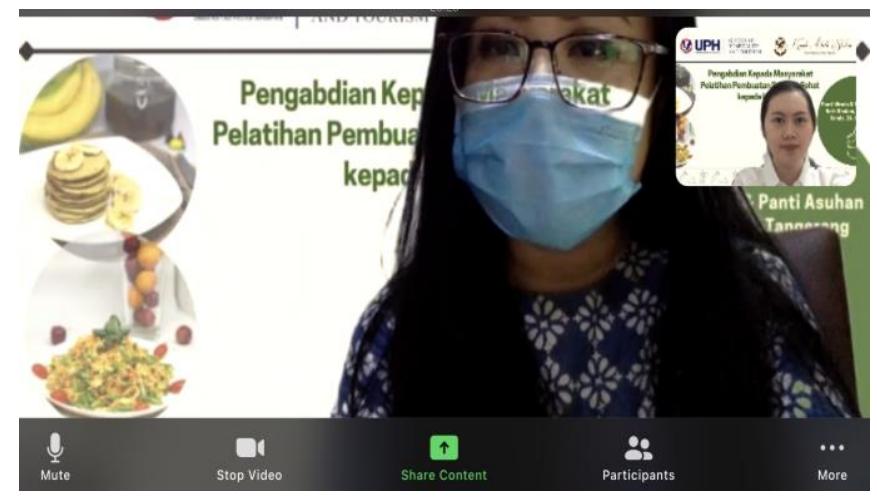

Gambar 3. Kata Pembuka Dari Ketua Tim

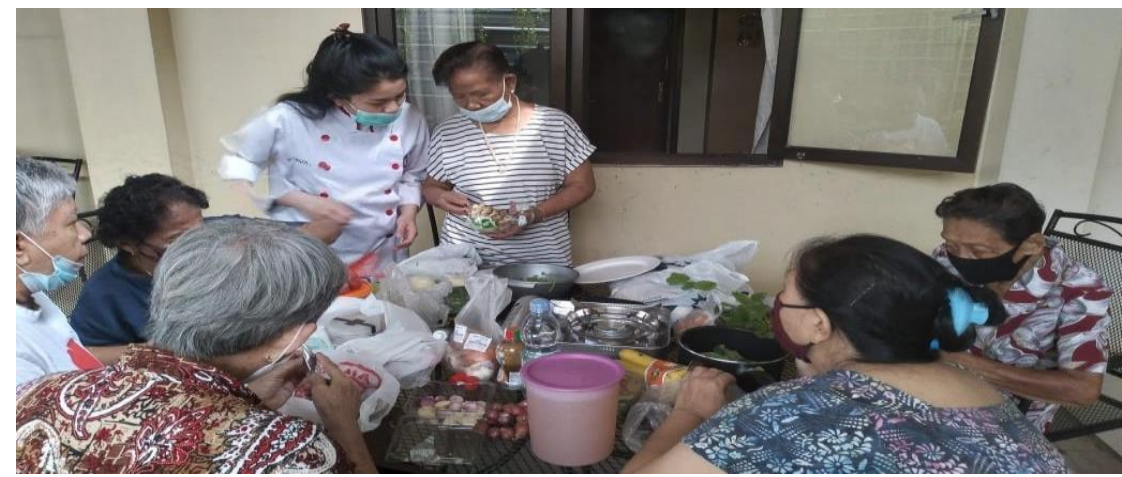

Gambar 4. Praktik Langsung pembuatan sarapan sehat

\section{Acknowledgement}

Tim Pengabdian Kepada Masyarakat mengucapkan banyak terima kasih kepada LPPM UPH yang telah memberikan kesempatan melaksanakan kegi atan pengabdian kepada masyarakat (PM-039-M/FPar/VI/2021). 


\section{Daftar Rujukan}

Abdi, A., Hariyanto, T., Arditani, V. M. (2017). Aktivitas Lansia Berhubungan dengan Status Kesehatan Lansia di Posyandu Permadi Kelurahan Tlogomas Kecamatan Lowokwaru Kota Malang, Nursing News, 2(3), 272-280. Diakses dari https://doi.org/10.33366/nn.v2i3.650.

Abidin A.Z., Julianto, E. K. (2020). Hubungan Fungsi Pemeliharaan Kesehatan Keluarga dengan Pencegahan Penularan COVID19 bagi Lansia di Desa Kadungrejo Baureno Bojonegoro, Jurnal Ilmu Keperawatan Komunitas, 3(2), 1-9. Diakses dari https://doi.org/10.32584/jikk.v3i2.788.

Akbar, D.M., Aidha, Z. (2020). Perilaku Penerapan Gizi Seimbang Masyarakat Kota Binjai pada Masa Pandemi COVID-19 Tahun 2020, Jurnal Menara Medika, 3(1), 15-21. Diakses dari https://doi.org/10.31869/mm.v3i1.2193.

Bogomolova, S., Carins, J., Dietrich, T., \& Dollman, J. (2020). Encouraging healthier choices in supermarkets: a co-design approach supermarkets. https://doi.org/10.1108/EJM-02-2020-0143

Bronfenbrenner, U. (2005). Making Human Beings Human: Bioecological Perspectives on Human Development, Sage Publications, Thousand Oaks, CA.

Bublitz, M.G., Hansen, J., Peracchio, L.A. and Tussler, S. (2019). Hunger and food well-being: Advancing research and practice", Journal ofPublic Policy andMarketing, Vol. 38, pp. 136-153.

Bublitz, M.G., Peracchio, L.A., Andreasen, A.R., Kees, J., Kidwell, B., Miller, E.G., Motley, C.M., Peter, P. C., Rajagopal, P., Scott, M.L. and Vallen, B. (2013). Promoting positive change: Advancing the food well-being paradigm", Journal of Business Research, Vol. 66 No. 8, pp. 1211-1218.

Hubner, I. B., Irene, N., \& Sitorus, B. (2021). Pemanfaatan Sayur Dalam Pembuatan Lasagna Non Daging. Jurnal Abdimas BSI Jurnal Pengabdian Kepada Masyarakat, 4(1), 2-7.

Juliana, J., Maleachi, S., Yulius, K. G., \& Situmorang, J. (2020). Pelatihan Pembuatan Salad Sayur Hidroponik dan Cara Pemasaran yang Tepat dalam E-Commerce. Jurnal Abdimas BSI Jurnal Pengabdian Kepada Masyarakat, 3(2), 208-216.

Lemy, D. M., Sihombing, S. O., Irene, N., Sitorus, B., Natalie, C., \& Leonarto, V. (2021). Pelatihan Kreasi Tteok Dengan Variasi Menu Sate Maranggi Dan Gulai Ayam. Jurnal Abdimas Berdaya: Jurnal Pembelajaran, Pemberdayaan Dan Pengabdian Masyarakat, 4, 12-23.

Nova Sitorus, Juliana, A. L. (2021). SOSIALISASI PERKEMBANGAN USAHA FOOD AND BEVERAGE DI MASA PANDEMI COVID-19 KEPADA SISWASISWI SMK PARIWISATA. Indonesian Journal of Community Service, 1(1), 134-147.

Nuriana, D., Rizkiyah, I., Lukman, E., Wibowo, H., Raharjo, S. T. (2019). Generasi Baby Boomers (Lanjut Usia) dalam Menghadapi Era Revolusi Industri 4.0, Jurnal Pekerjaan Sosial, 2(1), 32-46. Diakses dari https://doi.org/10.24198/focus.v2i1.23117.g11303.

RI, K. K. (2020). Panduan Gizi Seimbang pada Masa Pandemi COVID-19. Kementerian Kesehatan. 
Roberto, C.A., Swinburn, B., Hawkes, C., Huang, T.T., Costa, S.A., Ashe, M., Zwicker, L., Cawley, J.H. and Brownell, K. D. (2015). Patchy progress on obesity prevention: emerging examples, entrenched barriers, and new thinking", The Lancet, Vol. 385 No. 9985, pp. 2400-2409.

Senjaya, A. A. (2015). Gizi dan Gigi Lansia, Jurnal Kesehatan Gigi, 3(2), 123-129.

Sugiyono. (2011). Populasi, Sampel, Pengujian Normalitas Data. In Statistika Untuk Penelitian.

Utami, S.W.B., Tubiyono, Karyanto, P. (2020). Memacu Semangat Lansia melalui Kegiatan Budaya Seni, Jurnal Layanan Masyarakat (Journal of Public Service), 4(1), 176-188. Diakses dari http://dx.doi.org/10.20473/jlm.v4i1.2020.176-188.

Utami, E. S. W., \& Hariyanto, S. (2020). Organic Compounds: Contents and Their Role in Improving Seed Germination and Protocorm Development in Orchids. International Journal of Agronomy, 2020, 2795108. https://doi.org/10.1155/2020/2795108

Vanheuvelen, J. S., \& Vanheuvelen, T. (2017). RICH FOODS: THE CROSSNATIONAL EFFECTS OF HEALTHY EATING ON HEALTH. https://doi.org/10.1108/S1057-629020170000018002 